\title{
SYNTHESIS OF CHIRAL PYRIDINE BIS(OXAZOLINE) LIGANDS FOR NICKEL-CATALYZED ASYMMETRIC NEGISHI CROSS- COUPLINGS OF SECONDARY ALLYLIC CHLORIDES WITH ALKYLZINCS: 2,6-BIS[(4S)-4,5-DIHYDRO-4-(2-PHENYLETHYL)-2- OXAZOLYL]-PYRIDINE
}

\author{
Sha Lou and Gregory C. Fu'
}

\section{Abstract}

[Pyridine, 2,6-bis[(4R)-4,5-dihydro-4-(2-phenylethyl)-2-oxazolyl]-]

\section{Procedure}

\section{A. (S)-2-Amino-4-phenylbutan-1-ol (1)}

An oven-dried, 250-mL, two-necked, round-bottomed flask equipped with a condenser fitted with an argon inlet and a magnetic stirbar was purged with argon for $10 \mathrm{~min}$. Anhydrous THF $(200 \mathrm{~mL})$ (Note 1$)$ was added into the flask by syringe through the open neck under a positive pressure of argon. Next, lithium aluminum hydride ( $3.98 \mathrm{~g}, 105 \mathrm{mmol}, 1.50$ equiv) (Note 2) was added through the open neck under a positive pressure of argon, and the solution was stirred at $\mathrm{rt}$ until bubbling had ceased. L-Homophenylalanine $(12.5 \mathrm{~g}, 70.0$ mmol, 1.00 equiv) (Note 3 ) was added in portions (500 $\mathrm{mg}$ per portion) over $10 \mathrm{~min}$ through the open neck under a positive pressure of argon, during which time the solution gently refluxed. Upon completion of the addition, the open neck was capped, and the heterogeneous gray reaction mixture was heated at reflux in an oil bath for $24 \mathrm{~h}$. Next, the mixture was allowed to cool to rt, THF $(100 \mathrm{~mL})$ was added, and the solution was cooled to $0{ }^{\circ} \mathrm{C}$ in an ice bath. Water $(10 \mathrm{~mL})$ was added dropwise over $10 \mathrm{~min}$ (Note 4), and then a solution of $\mathrm{NaOH}(2.5 \mathrm{M}, 20 \mathrm{~mL})$ was added in one portion. The resulting mixture was heated at reflux for $20 \mathrm{~min}$ until the color of the precipitate changed from gray to white. The warm solution was filtered through a Büchner funnel that contained a bed of celite $(1.0 \mathrm{~cm}$ height), and the precipitate was washed with warm THF $(100 \mathrm{~mL})$. The filtrate was concentrated under reduced pressure (20 torr) to remove the THF and most the water. The residue was dried azeotropically with toluene (two $50-\mathrm{mL}$ portions) by rotary evaporation (20 torr) and then under high vacuum ( 0.5 torr) for $2 \mathrm{~h}$, which yielded the desired $\beta$-amino alcohol 1 as a white solid (10.6-11.0 g, 92-95\% yield) (Note 5) that was used in the next step without further purification.

\section{B. (R)-2-Amino-4-phenylbutan-1-ol (2)}

An oven-dried, 250-mL, two-necked, round-bottomed flask equipped with a condenser fitted with an argon inlet and a magnetic stirbar was purged with argon for $10 \mathrm{~min}$. Anhydrous

\footnotetext{
${ }^{1}$ Department of Chemistry, Room 18-290, Massachusetts Institute of Technology, Cambridge, Massachusetts 02139; gcf@mit.edu..
} 
THF (200 mL) (Note 1) was added into the flask by syringe through the open neck under a positive pressure of argon. Next, lithium aluminum hydride ( $4.56 \mathrm{~g}, 120 \mathrm{mmol}, 1.50$ equiv) (Note 2) was added over $5 \mathrm{~min}$ through the open neck under a positive pressure of argon. The solution was stirred at $\mathrm{rt}$ for $5 \mathrm{~min}$, and then $\mathrm{D}$-homophenylalanine ethyl ester hydrochloride (19.5 g, $80.0 \mathrm{mmol}, 1.00$ equiv) (Note 6) was added in portions (500 mg per portion) over $10 \mathrm{~min}$ through the open neck under a positive pressure of argon, during which time the solution gently refluxed. Upon the completion of the addition, the open neck was capped, and the heterogeneous gray reaction mixture was heated at reflux in an oil bath for $24 \mathrm{~h}$. Next, the mixture was allowed to cool to rt, THF $(100 \mathrm{~mL})$ was added, and the solution was cooled to $0{ }^{\circ} \mathrm{C}$ in an ice bath. Water $(10 \mathrm{~mL})$ was added dropwise over $10 \mathrm{~min}$ (Note 4), and then a solution of $\mathrm{NaOH}(2.5 \mathrm{M}, 20 \mathrm{~mL})$ was added in one portion. The resulting mixture was heated at reflux for 20 min until the color of the precipitate changed from gray to white. The warm solution was filtered through a Büchner funnel that contained a bed of celite $(1.0 \mathrm{~cm}$ height $)$, and the precipitate was washed with warm THF $(100 \mathrm{~mL})$. The filtrate was concentrated under reduced pressure (20 torr) to remove the THF and most of the water. The residue was dried azeotropically with toluene (two 50 -mL portions) by rotary evaporation (20 torr) and then under high vacuum ( 0.5 torr) for $2 \mathrm{~h}$, which yielded the desired $\beta$-amino alcohol 2 as a white solid (12.5-13.0 g, 94-98\% yield) (Note 7) that was used in the next step without further purification.

\section{2,6-Bis[(4R)-4,5-dihydro-4-(2-phenylethyl)-2-oxazolyl]pyridine (3)}

(Note 8) An oven-dried, 250-mL, two-necked, round-bottomed flask equipped with a condenser fitted with an argon inlet and a magnetic stirbar was purged with argon for 10 min. 2,6-Pyridinedicarbonitrile ( $2.58 \mathrm{~g}, 20.0 \mathrm{mmol}, 1.00$ equiv) (Note 9), anhydrous toluene (120 mL; added by syringe) (Note 10), and zinc trifluoromethanesulfonate (363 mg, 1.00 mmol, 0.050 equiv) (Note 11) were added through the open neck under a positive pressure of argon, and the mixture was stirred at $\mathrm{rt}$ for $5 \mathrm{~min}$. A solution of $(R)$-2-amino-4phenylbutan-1-ol (2) (6.60 g, $40.0 \mathrm{mmol}, 2.00$ equiv) in toluene $(30.0 \mathrm{~mL})$ was added, the open neck was capped, and the reaction mixture was heated at reflux in an oil bath for $24 \mathrm{~h}$. Next, the reaction mixture was allowed to cool to rt, and it was diluted with ethyl acetate $(300 \mathrm{~mL})$. The solution was washed with a saturated aqueous solution of $\mathrm{NaHCO}_{3}(200 \mathrm{~mL})$ and brine $(200 \mathrm{~mL})$, and then it was dried over anhydrous $\mathrm{MgSO}_{4}(20 \mathrm{~g})$ and filtered through a Büchner funnel that contained a bed of celite $(1.0 \mathrm{~cm}$ height). The filtrate was concentrated under reduced pressure on a rotary evaporator (20 torr), and the residue was purified by column chromatography on silica gel $(10 \mathrm{~cm}$ diameter $\times 20 \mathrm{~cm}$ height), eluting with ethyl acetate:hexanes: $\mathrm{Et}_{3} \mathrm{~N}(1: 1: 0.02)$ (Note 12), which afforded the desired pyridine derivative 3 (6.89-7.06 g, 81-83\% yield, >99\% ee) as a white solid (Note 13 and Note 14).

\section{Notes}

1. THF (99+\%) was purchased from J.T. Baker (water content: $24 \mathrm{ppm}$ ) and purified by passage through activated alumina under argon.

2. Lithium aluminum hydride (97\%) was purchased from Alfa Aesar and used as received.

3. ${ }_{-}-H o m o p h e n y l a l a n i n e ~(98+\%)$ was purchased from $\mathrm{CNH}$ Technologies, Inc. and used as received.

4. Quenching excess lithium aluminum hydride with water is a highly exothermic process that produces $\mathrm{H}_{2}$. Dropwise addition of water is recommended, and care should be taken to efficiently cool and stir the reaction mixture. The quenching should be conducted in an efficient fume hood in order to safely vent the $\mathrm{H}_{2}$ gas. 
5. The purity of compound $\mathbf{1}(95 \%)$ was determined by HPLC analysis $\left(\mathrm{t}_{\mathrm{r}}=4.21 \mathrm{~min}\right)$ with an Agilent 1100 Series HPLC system equipped with an Eclipse XDB-C18 column (length $150 \mathrm{~mm}$, I.D. $4.6 \mathrm{~mm}$, particle size $5 \mu \mathrm{m}$ ), using a $2 \% \rightarrow 98 \%$ $\mathrm{MeOH} /(0.2 \% \mathrm{AcOH}$ in water $)$ gradient for $3 \mathrm{~min}$, then $98 \% \mathrm{MeOH} /(0.2 \% \mathrm{AcOH}$ in water) for $5 \mathrm{~min}$, with a flow rate of $0.8 \mathrm{~mL} / \mathrm{min}$. Compound 1 can be purified via column chromatography on silica gel (see Note 7 for conditions and characterization data). $[\alpha]^{21} \mathrm{D}=+0.76\left(\mathrm{c}=1.0, \mathrm{CHCl}_{3}\right)$.

6. D-Homophenylalanine ethyl ester hydrochloride $(\geq 98 \%)$ was purchased from Fluka and used as received.

7. The purity of compound $2(93 \%)$ was determined by HPLC analysis, using the same conditions as for compound $\mathbf{1}$. Compound $\mathbf{2}$ can be purified via column chromatography on silica gel, eluting with $\mathrm{MeOH}: \mathrm{CH}_{2} \mathrm{Cl}_{2}: \mathrm{Et}_{3} \mathrm{~N}$ (5:95:2). $\mathrm{R}_{f}=0.4$ (MeOH:CH $\left.\mathrm{CH}_{2}, 1: 9\right)$. Compound 2 has the following properties: ${ }^{1} \mathrm{H} \mathrm{NMR}\left(\mathrm{CDCl}_{3}\right.$, $500 \mathrm{MHz}) \delta: 7.27(\mathrm{t}, J=8.0 \mathrm{~Hz}, 2 \mathrm{H}), 7.16-7.18(\mathrm{~m}, 3 \mathrm{H}), 3.58(\mathrm{dd}, J=10.5,3.5 \mathrm{~Hz}$, $1 \mathrm{H}), 3.31(\mathrm{dd}, J=10.5,7.5 \mathrm{~Hz}, 1 \mathrm{H}), 2.82-2.86(\mathrm{~m}, 1 \mathrm{H}), 2.70-2.76(\mathrm{~m}, 1 \mathrm{H})$, 2.61-2.66 (m, 1H), $1.92(\mathrm{br} \mathrm{s}, 3 \mathrm{H}), 1.71-1.77(\mathrm{~m}, 1 \mathrm{H}), 1.54-1.60(\mathrm{~m}, 1 \mathrm{H}) ;{ }^{13} \mathrm{C}$ NMR ( $\left.\mathrm{CDCl}_{3}, 125 \mathrm{MHz}\right) \delta$ : 141.9, 128.6, 128.4, 126.1, 66.4, 52.4, 35.9, 32.5; IR (film) 3352, 2924, 1601, 1495, 1454, 1367, 1055, 748, $699 \mathrm{~cm}^{-1}$; LRMS (ESI) calcd for $\mathrm{C}_{10} \mathrm{H}_{16} \mathrm{NO}(\mathrm{M}+\mathrm{H}) 166.1$; found $166.1 ;[\alpha]^{21} \mathrm{D}=-0.78\left(\mathrm{c}=1.05, \mathrm{CHCl}_{3}\right)$; mp $40-43{ }^{\circ} \mathrm{C}$.

8. 2,6-Bis[(4S)-4,5-dihydro-4-(2-phenylethyl)-2-oxazolyl]pyridine (97\%) is available from Aldrich.

9. 2,6-Pyridinedicarbonitrile (97\%) was purchased from Aldrich and used as received.

10. Toluene (99+\%) was purchased from J.T. Baker (water content: $<0.01 \%$ ) and purified by passage through activated alumina under argon.

11. Zinc trifluoromethanesulfonate (98\%) was purchased from Strem and used as received.

12. Column chromatography was performed on Sorbent Technologies $60 \AA$ A silica gel.

13. By conducting the reaction with anhydrous zinc chloride as the catalyst (10\%) and chlorobenzene as the solvent at $120^{\circ} \mathrm{C}$ for $24 \mathrm{~h}$, the pybox ligand can be generated in comparable yield. 2

14. Compound 3 has the following properties: ${ }^{1} \mathrm{H}$ NMR $\left(\mathrm{CDCl}_{3}, 500 \mathrm{MHz}\right) \delta: 8.21(\mathrm{~d}$, $J=8.0 \mathrm{~Hz}, 2 \mathrm{H}), 7.89(\mathrm{t}, J=8.0 \mathrm{~Hz}, 1 \mathrm{H}), 7.20-7.31(\mathrm{~m}, 10 \mathrm{H}), 4.59(\mathrm{t}, J=8.5 \mathrm{~Hz}$, $2 \mathrm{H}), 4.33-4.39(\mathrm{~m}, 2 \mathrm{H}), 4.16(\mathrm{t}, J=8.5 \mathrm{~Hz}, 2 \mathrm{H}), 2.84-2.89(\mathrm{~m}, 1 \mathrm{H}), 2.76-2.81(\mathrm{~m}$, $1 \mathrm{H}), 2.05-2.11(\mathrm{~m}, 1 \mathrm{H}), 1.90-1.96(\mathrm{~m}, 1 \mathrm{H}) ;{ }^{13} \mathrm{C} \mathrm{NMR}\left(\mathrm{CDCl}_{3}, 125 \mathrm{MHz}\right) \delta: 162.5$, 146.9, 141.6, 137.5, 128.5, 128.4, 126.1, 125.9, 73.3, 66.5, 37.6, 32.4; IR (film) 3438, 2926, 2238, 1643, 1575, 1496, 1454, 1359, 1248, 1171, 1108, 1076, 975, 910, 735, $701 \mathrm{~cm}^{-1}$; LRMS (ESI) calcd for $\mathrm{C}_{27} \mathrm{H}_{28} \mathrm{~N}_{3} \mathrm{O}_{2}(\mathrm{M}+\mathrm{H}) 426.2$; found $426.2 ;[\alpha]^{21} \mathrm{D}=+141\left(\mathrm{c}=1.15, \mathrm{CHCl}_{3}\right) ; \mathrm{mp} 86-88^{\circ} \mathrm{C}$. The enantiomeric excess of 3 was determined by supercritical fluid chromatography (SFC) analysis on a Berger SFC MiniGram system: Chiralcel OD-H column (length $250 \mathrm{~mm}$, I.D. $4.6 \mathrm{~mm}$ ); solvent system: $20 \% \mathrm{MeOH}, 3.0 \mathrm{~mL} / \mathrm{min}$; retention times: $19.00 \mathrm{~min}((R)-$ enantiomer), $21.73 \mathrm{~min}((S)$-enantiomer).

\section{Waste Disposal Information}

All toxic materials were disposed of in accordance with "Prudent Practices in the Laboratory" National Academy Press: Washington, DC, 1995. 


\section{Discussion}

Chiral pyridine-2,6-bisoxazolines (pybox) form tridentate complexes with a variety of metals, and they have proved to be highly effective ligands in asymmetric catalysis. $3 \mathrm{We}$ have reported several examples of enantioselective Negishi cross-couplings of secondary alkyl halides with organozinc reagents that are catalyzed by Ni/pybox complexes.4, 5 When $\alpha$-bromo amides $4 \mathrm{a}$ and benzylic bromides $4 \mathrm{~b}$ are employed as electrophiles, commercially available $i$-Pr-Pybox is the ligand of choice. However, for Negishi couplings of allylic chlorides, $\mathrm{CH}_{2} \mathrm{CH}_{2} \mathrm{Ph}$-pybox is the optimal ligand from the standpoints of enantioselectivity and yield.4c Herein, we describe procedures for the synthesis of $\mathrm{CH}_{2} \mathrm{CH}_{2} \mathrm{Ph}$-pybox.<smiles>[R]O[R6]#[R6]</smiles>

The procedure is based on a general route developed by Pires and coworkers.6 $(R)$ - and $(S)$-2-Amino-4-phenylbutan-1-ol are readily available by reduction of homophenylalanine or an ester derivative.

\section{Appendix}

\section{Chemical Abstracts Nomenclature; (Registry Number)}

Ł-Homophenylalanine: Benzenebutanoic acid, $\alpha$-amino-, $(\alpha \mathrm{S})-;$ (943-73-7)

D-Homophenylalanine ethyl ester hydrochloride: Benzenebutanoic acid, $\alpha$-amino-, ethyl ester, hydrochloride (1:1), $(\alpha \mathrm{R})-;(90940-54-8)$

Lithium aluminum hydride: Aluminate(1-), tetrahydro-, lithium (1:1), (T-4)-; (16853-85-3)

(S)-2-Amino-4-phenylbutan-1-ol: Benzenebutanol, $\beta$-amino-, ( $\beta S)-; ~(27038-09-1)$

(R)-2-Amino-4-phenylbutan-1-ol: Benzenebutanol, $\beta$-amino-, ( $\beta \mathrm{R})-$; (761373-40-4)

2,6-Pyridinedicarbonitrile; (2893-33-6)

Zinc trifluoromethanesulfonate: Methanesulfonic acid, 1,1,1-trifluoro-, zinc salt (2:1); (54010-75-2)

2,6-Bis[(4R)-4,5-dihydro-4-(2-phenylethyl)-2-oxazolyl]pyridine: Pyridine, 2,6-bis[(4R)-4,5dihydro-4-(2-phenylethyl)-2-oxazolyl]-

\section{References}

2. Witte H, Seeliger W. Angew. Chem. Int. Ed. 1972; 11:287-288. See also: Chelucci G, Deriu S, Pinna GA, Saba A, Valenti R. Tetrahedron: Asymmetry. 1999; 10:3803-3809.

3. For leading references to the use of oxazolines as ligands in asymmetric catalysis, see: (a) Hargaden GC, Guiry PJ. Chem. Rev. 2009; 109:2505-2550. [PubMed: 19378971] (b) McManus HA, Guiry PJ. Chem. Rev. 2004; 104:4151-4202. [PubMed: 15352789] (c) Desimoni G, Faita G, Quadrelli P. Chem. Rev. 2003; 108:3119-3154. [PubMed: 12914494] 
4. (a) Fischer C, Fu GC. J. Am. Chem. Soc. 2005; 127:4594-4595. [PubMed: 15796523] (b) Arp FO, Fu GC. J. Am. Chem. Soc. 2005; 127:10482-10483. [PubMed: 16045323] (c) Son S, Fu GC. J. Am. Chem. Soc. 2008; 130:2756-2757. [PubMed: 18257579] (d) Smith SW, Fu GC. J. Am. Chem. Soc. 2008; 130:12645-12647. [PubMed: 18763769] (e) Lundin PM, Esquivias J, Fu GC. Angew. Chem. Int. Ed. 2009; 48:154-156.

5. For an overview, see: Rudolph A, Lautens M. Angew. Chem. Int. Ed. 2009; 48:2656-2670.

6. Cornejo A, Fraile JM, García JI, Gil MJ, Martínez-Merino V, Mayoral JA, Pires E, Villalba I. Synlett. 2005:2321-2324. 